\title{
Softs Skills Teacher Camp of Adventure Training to increase teachers' commitment in Pathani Thailand
}

\author{
Hadi Suyono $^{1}$, Mus-ab Buenae ${ }^{2}$ \\ ${ }^{1}$ Faculty of Psychology, Universitas Ahmad Dahlan, Indonesia \\ ${ }^{2}$ Daruliktisam Foundation Pathani, Thailand \\ ${ }^{2}$ Kulliyatul Dakwah wa Ushuluddin, Islamic University of Madinah, Saudi Arabia \\ ${ }^{1}$ hadi.suyono@psy.uad.ac.id., ${ }^{2}$ focusme.arin@gmail.com.
}

ARTICLE INFO

Article history

Received 30 April 2020

Revised 26 June 2020

Accepted 30 July 2020

Keywords

commitment

soft skills

teacher

\begin{abstract}
Commitment is needed to overcome various obstacles while teaching in conflict areas. This study aimed to increase teacher commitment in the Pathani conflict area, Southern Thailand, through Soft Skills Teacher Camp of Adventure Training. A quantitative approach using a quasi-experimental method was used in this study. Thirty teachers from six schools with a maximum age of 35 years participated in soft skills training. The Soft Skills Teacher Camp of Adventure Training consists of six sessions on six different soft skills, which are motivation, stress management, creativity, teamwork, communication skills, and leadership. The commitment scale consisting of three aspects: affective commitment, normative commitment, and continuance commitment, was used to collect the data. Paired Sample $t$-test was used to analyze the data. The result highlighted a significant difference between the pretest and posttest scores of teachers' commitment in the Pathani, Southern Thailand. These findings imply that the Soft Skills Teacher Camp of Adventure Training increases the commitment of teachers who teach in the Pathani, Southern Thailand.
\end{abstract}

\section{Introduction}

Pathani has historical roots as the land of the Malay Archipelago of the North. The Kingdom of Thailand is at the center of the spread of Islam in Southern Thailand. Since 1785 the kingdom has been ruled by the Kingdom of Siam. History showed that the Government of Thailand later controls the Kingdom of Siam. The occupation of the Thai Government, which has different beliefs with the majority of the Pathani people, has been challenged by the Pathani people (Buenae, 2017).

Research has shown that the diverse religious practices between the Pathani people and most Thai people have contributed to the dynamic of conflict in Southern Thailand (Engvall \& Andersson, 2014). Other studies have noted that the differing belief between the Pathanis and general public in Thailand also causes conflict to arise (Harish, S., 2006). There is a resistance because the government is trying to assimilate cultures and religions that are different from the culture of the Pathani people (Pongsudhirak, 2006).

The conflict that took place in Pathani impacts the level of commitment of teachers who teach at Pathani, with teachers fearing the implication of having to teach in conflict areas. Previous reports that highlighted that 200 teachers died as victims of violence during the conflict also resulting teachers prefer to stay at home to avoid acts of violence and to remain safe (Buenae, 2017).

Commitment can be understood as individual psychological reactions to their work. A person who is highly committed to his/her work will give an emotional, psychological response, as shown in his/her liking or love for his/her work (Lee, T. et al., 2000). Commitment can also be explained as a psychological strength, self-identification, and 
positive feelings towards the job (Ibrahim, M. et al., 2013). Commitment can foster a love for one's work, psychological strength, and positive feelings, further encouraging teachers to continue teaching in conflict areas. Research evidence showed that commitment could strengthen the role of individuals in their work (Park, J. et al., 2018).

Commitment to pursuing the profession as a teacher may be increased through soft skills training. Soft skills are psychological abilities and competencies that are manifested through personality characteristics to be optimistic in every situation including motivation, stress management, creativity, teamwork, communication skills, and leadership (Attakorn et al., 2014; Crawford et al., 2020; Dubey, S. \& Tiwari, 2020; Ngang, K. et al., 2015).

Motivation is one of the soft skills, as a driving force, energy, enthusiasm, and passion for doing work in challenging situations, that can foster teacher commitment to work in challenging areas such as conflict areas (Altintas et al., 2020; Fernet et al., 2016). Stress management is the part of soft skills that developed commitment by an understanding of stresses, events, overload, and daily problems related to the work so that it can be appropriately managed. Proper stress management will grow a commitment to remain devoted to the work (Ly et al., 2014; Smyth et al., 2015). Creativity is a mental process of developing ideas or solutions when facing problems by producing various alternative concepts to obtain answers and problem-solving strategies. Creativity builds the commitment of by develop ideas, find alternative solutions to problems, and find answers to problems to become educators (Mukherjee et al., 2016). While teamwork influences the commitment as an effort to involve individuals to contribute to the group producing optimal performance (Le Blanc \& González-Romá, 2012; Neininger et al., 2010). Communication skills are essential to developing commitment as it fosters open interaction, mutual understanding, and friendship. Communication is useful for relations with students, peers, and leaders who love and strengthen each other in interpersonal relationships (Park et al., 2012; Raina \& Roebuck, 2016). Leadership also contributes to forming teacher commitment through the responsibility of influencing others to achieve common goals (Jackson et al., 2013; Kim et al., 2012; Liu \& Werblow, 2019; Steffens et al., 2018).

Previous studies showed that soft skills training is effective in influencing the quality of teachers in carrying out their profession (Cimermanova, 2015; Colella et al., 2019; Gillies, 2004; Ngang et al., 2015; Ngang \& Chan, 2015). Previous research showed soft skills training with TCA increased the commitment of remote area teachers in Indragiri Hilir, Riau, Indonesia (Amiruddin, 2017). Based on this finding, the TCA model soft skills training was able to increase teachers' commitment in remote areas, which was subsequently applied to strengthen teacher commitment in Pathani, Thailand. Therefore this study focuses on soft skills training to increase teacher commitment in Pathani through Teacher Camp of Adventure Training (TCA).

\section{Method}

\section{Research Design}

This study used a quasi-experimental design with experiments with a one-group pretestposttest design. Teacher Camp of Adventure is an outdoor training specifically designed to increase the commitment of teachers through experiential learning. The Teacher Camp of Adventure training was modified from previous research conducted by Amiruddin (2017).

\section{Participants}

Thirty teachers from six schools in the Pathani, Thailand, with a maximum age of 35 years old, participated in this study. Participants consisted of 24 women and six men. The participants have experienced teaching for at least one year, being a classroom teacher, and a teacher in the field of study. The teacher has the status of a non-permanent teacher, foundation teacher, and government teacher. 


\section{Data Collection}

The teacher commitment scale was used to collect the data collection in the pretest and posttest stages. This scale consists of 27 items in three aspects: affective commitment, normative commitment, and continuance commitment (Allen \& Meyer, 1996; Meyer et al., 2002). An example of an affective commitment item is "continue to teach in conflict areas despite emotional distress." An example of the normative commitment aspect is, "even though I teach in conflict areas, I feel guilty when I am unable to grow students' character." An example of the item of continuance commitment is "despite the limited rewards of teaching in conflict areas, I still try to educate students as well as possible." The scale had an alpha reliability coefficient $(\alpha)$ of .873 with a range of item discrimination index between $.379-.873$.

\section{Research Procedure}

First, participants filled the teacher commitment scale as a pretest. The pretest is given two days before providing treatment, following by the implementation of the Teacher Camp of Adventure Training. Participants worked on the learning contracts before the first session of training that was communication skills through the game Finding Missing Families. Based on the game, participants were taught about effective communication skills for teachers. The second session of training was motivation skills using the game Who Am I? A debrief about having motivation as a useful soft skill for teachers in conflict areas was conducted after the game. The third session of training was stress management that delivered through the game Self Reflection to develop stress management as a psychological force on persisting in teaching in conflict areas. The fourth session was leadership skills conducted through the game Train Ball with an explanation of the importance of leadership and carrying out the task as a teacher. The game Moving Boom was used to teach about teamwork in the fifth session of the training, follow by debriefing about how teamwork could support teachers' performance. The last session was creativity deliver through the game Speed and Creative to show the importance of creativity for teachers. After the treatment performed, participants were then asked to complete the posttest. Posttest was given six days after giving treatment.

\section{Data Analysis}

Data were analyzed using the Paired Sample $t$-test with the Statistics Product and Service Solution (SPSS) program in Version 20.

\section{Results}

The result shows that there are significant differences in the pretest and posttest scores of teacher commitment $(t=-7.794 ; p<.01)$. Figure 1 shows the mean of the posttest is significantly higher than that of the pretest. Based on the result Soft Skills Teacher Camp of Adventure (TCA) Training increase the commitment of teachers in Pathani.

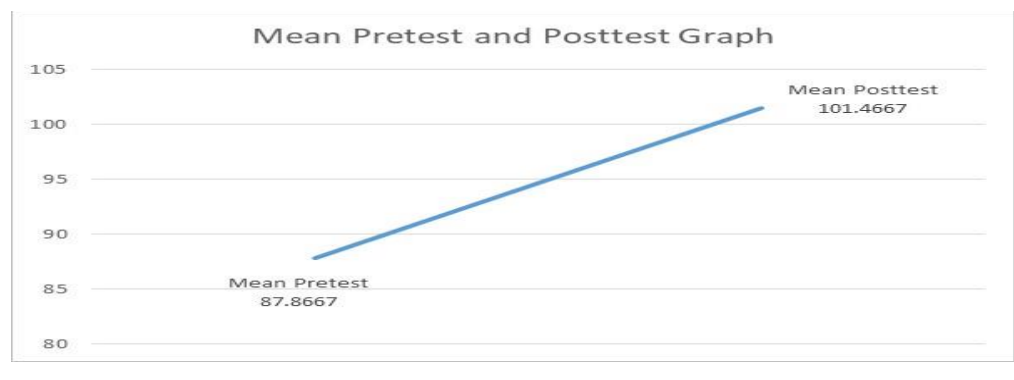

Figure 1. Mean pretest and posttest score on teacher commitment 
Figure 2 shows the pretest and posttest scores of each participant in this study. Only one of thirty participants had a lower score in posttest than pretest. Majority participants have an increasing score on commitment after involving in the Soft Skill Teacher Camp Adventure Training.

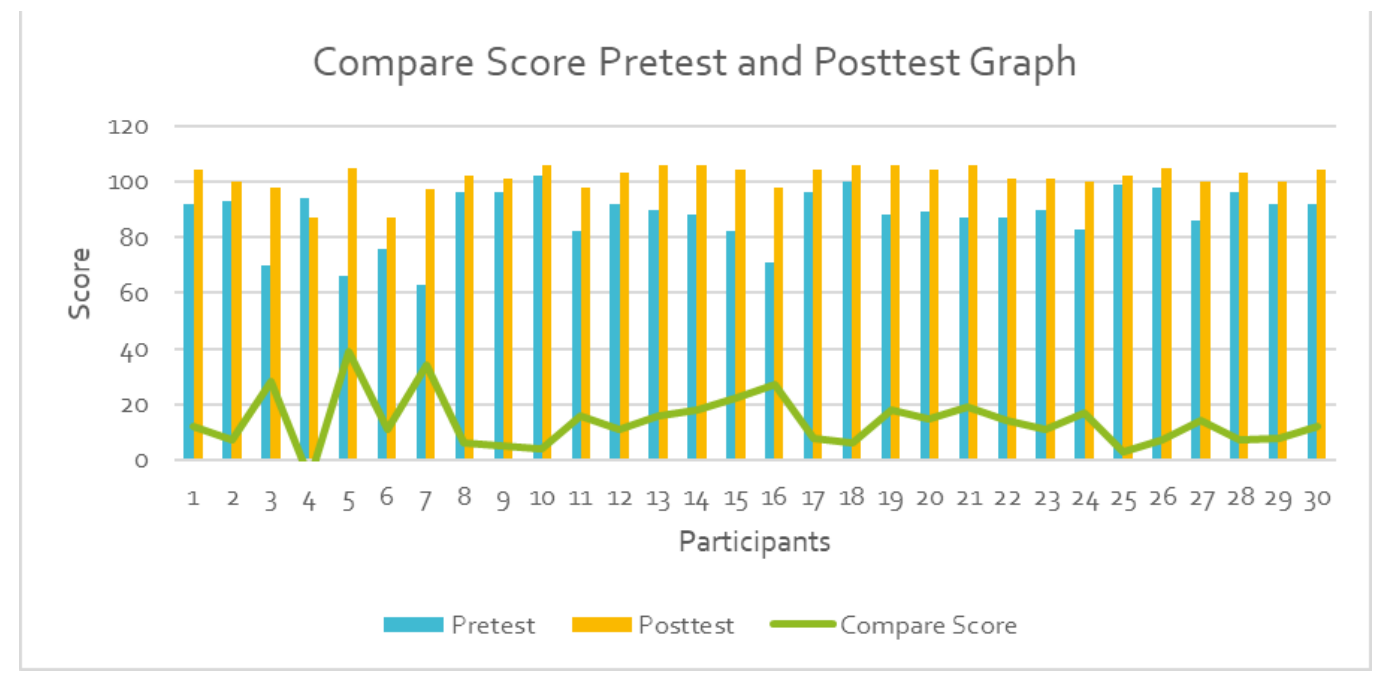

Figure 2. Compare score pretest and posttest of all participants

\section{Discussion}

Soft skills training consists of motivation, stress management, creativity, teamwork, communication skills, and leadership increase teacher commitment. These findings confirm the previous research on the importance of soft skills for teachers (Fleischmann, 2013; Pachauri \& Yadav, 2014; Somprach et al., 2014). Each soft skills component that delivered though the Teacher Camp of Adventure Training contributes to the increasing of commitment among teachers.

Communication skills increase the commitment aspects of normative commitment and affective commitment (Matin et al., 2010). The development of teachers' communication skills into more positive, flexible, and open that will affect the teachers' selfadjusted, passionate, attitudes, and also the skills to manage interactions with leaders, fellow teachers, students, and stakeholders (Mohd Yusof \& Halim, 2014; Yeșil, 2010). Soft skills were able to foster normative commitment, namely positive attitude, openness, selfadjustment, and the capability to manage interactions to form a moral obligation to serve the profession (Meyer \& Parfyonova, 2010). Communication skills also affected the increase in affective commitment, namely the flexibility of interaction and passion for working to build value in maintaining the quality of education (Ghouri et al., 2019; Tang \& Vandenberghe, 2020).

Motivational skills that contained several indicators that are responsible, open to new challenges, wanting better achievements, and trying to obtain optimal results (Han \& Yin, 2016). Motivation skills increase teachers' commitment by enhancing the continuance commitment that is to continue to carry out their duties and the affective commitment to affirm values in self as teachers to educate students (Canrinus et al., 2012).

Stress management is essential when individuals experience pressure to carry out tasks by doing positive coping strategies to adequately overcome stress, as the ability to self-identify stress (Herman et al., 2020; Jamal et al., 2017). Expertise in managing stress can strengthen teacher's values (affective commitment) when experiencing problems 
regarding work in conflict areas (Dharmanegara et al., 2018). Therefore stress management increase commitment, specifically continuance commitment and affective commitment

With leadership, teachers have high responsibility, carrying out activities that have a positive role in the environment, a strong influence on colleagues, and having an advantage in influencing others (Aydin et al., 2013). The leadership skill strengthens commitment in terms of developing discipline, responsibility, fostering enthusiasm, building selfconfidence, and being able to be a role model to others. These indicators contributed to the forming of commitment, specifically affective and normative commitment (Liu et al., 2020; Ross et al., 2016).

Teamwork skills were also delivered at the TCA training aiming at increasing teacher commitment. With teamwork skills, teachers have an awareness of doing the task as a shared responsibility, contributing to each other in solving problems, maximizing the potential, and willingness to share with the group (Shen \& Bai, 2019). These indicators could increase teacher commitment (Moses et al., 2017). Ability to work as a team was able to foster teacher commitment due to the ability to handle various problems on duty. Teachers were able to solve problems because the issues they faced were shared responsibilities, in which each one on them contributed to the solution of the problem. Such dynamics shaped the commitment of teachers to continue teaching.

Creativity was the last delivered in TCA soft skills training. Individuals with good creativity were able to carry out thought processes in looking for alternatives to solve problems, exhibit more problem-solving ideas, have new ideas, and carried out evaluations of problem-solving decisions (Jónsdóttir, 2017; Paek \& Sumners, 2019). Such abilities may increase commitment. The ability to find various ways to overcome the problem, achieve adequate knowledge when facing challenges, find solutions to obstacles, and provide evaluation aimed at making improvements to previous decisions enabled teachers to solve problems regarding work. Such dynamics explained why teachers who are highly committed overcome various issues experienced while teaching.

The absence of a control group becomes the limitation of this study. The quasiexperiment design was chosen based on the consideration of the condition of research area. Future research is suggested to apply true experiment design with experiment and control groups, to ensure that the increasing commitment among the teacher is merely influenced by the soft skills training.

\section{Conclusion}

The commitment of teachers who teach in the Pathani, Southern Thailand, was increased by involving the Soft Skills Teacher Camp of Adventure Training. The soft skills training consists of motivation, stress management, creativity, teamwork, communication skills, and leadership has been proven to escalate the commitment of teachers. Therefore the Teacher Camp of Adventure Training can be used as a way to enhance the commitment among workers, especially teachers.

\section{References}

Allen, N. J., \& Meyer, J. P. (1996). Affective, continuance, and normative commitment to the organization: An examination of construct validity. Journal of Vocational Behavior, 49(3), 252-276. https://doi.org/10.1006/jvbe.1996.0043

Altintas, E., Karaca, Y., Moustafa, A., \& Haj, E., M. (2020). Effect of best possible self intervention on situational motivation and commitment in Academic Context. Learning 
and Motivation, 69, 1-7. https://doi.org/10.1016/j.imot.2019.101599

Amiruddin. (2017). The effectiveness of increasing teacher commitment through soft skills training using TCA (Teacher Camp of Adventure) model for teachers in remote area. (Master Thesis), Universitas Ahmad Dahlan, Yogyakarta.

Attakorn, K., Tayut, T., Pisitthawat, K., \& Kanokorn, S. (2014). Soft skills of the new teacher in the secondary schools of Khon Kaen Secondary Educational Service Area 25, Thailand. Procedia-Social and Behavioral Sciences, 112, 1010-1013. https://doi.org/10.1016/j.sbspro.2014.01.1262

Aydin, A., Sarier, Y., \& Uysal, S. (2013). The effect of school principals' leadership styles on teachers' organizational commitment and job satisfaction. Educational Sciences: Theory and Practice, 13(2), 806-811. https://files.eric.ed.gov/fulltext/EJ1017309.pdf.

Buenae, M. (2017). Focuss group discuss report: Education in Pathani conflict. Pathani: Darul Iktisom Foundation.

Canrinus, E. T., Helms-Lorenz, M., Beijaard, D., Buitink, J., \& Hofman, A. (2012). Selfefficacy, job satisfaction, motivation and commitment: Exploring the relationships between indicators of teachers' professional identity. European Journal of Psychology of Education, 27(1), 115-132. https://doi.org/10.1007/s10212-011-0069-2

Cimermanova, I. (2015). Creativity in EFL teacher training and its transfer to language teaching. Procedia-Social and Behavioral Sciences, 197, 1969-1975. https://doi.org/10.1016/j.sbspro.2015.07.562.

Colella, M., Bisanzo, M., Farquhar, C., Nambaziira, R., Carter, E., Gimbel, S., \& O’Malley, G. (2019). Implementation and evaluation of an innovative leadership and teacher training program for non-physician emergency medicine practitioners in Uganda. African Journal of Emergency Medicine, 9(1), 25-29. https://doi.org/10.1016/j.afjem.2018.12.002.

Crawford, A., Weber, R., M., \& Lee, H., J. (2020). Using a grounded theory approach to understand the process of teaching soft skills on the job so to apply it in the hospitality classroom. Journal of Hospitality, Leisure, Sport \& Tourism Education, 26, 1-7. https://doi.org/10.1016/j.jhlste.2020.100239

Dharmanegara, I. B. A., Yogiarta, I. M., \& Komang, I. B. (2018). Work-family conflict, family-work conflict and its effect on emotional exhaustion and affective commitment. International Journal of Academic Research in Business and Social Sciences, 8(1), 185-200. https://doi.org/10.6007/IJARBSS/v8-i1/3803.

Dubey, S., R., \& Tiwari, V. (2020). Operationalisation of soft skills attributes and determining the existing gap in novice ICT professionals. International Journal of Information Management, $\quad 50, \quad 375-386$. https://doi.org/10.1016/j.ijinfomgt/2019.09.006

Engvall, A., \& Andersson, M. (2014). The dynamics of conflict in southern Thailand. Asian Economic Papers, 13(3), 169-189. https://doi.org/10.1162/ASEP_a_00303

Fernet, C., Trepanier, G., S., Austin, S., \& Cote, L., J. (2016). Committed, inspiring, and healthy teachers: How do school environment and motivational factors facilitate optimal functioning at career start? Teaching and Teacher Education, 59, 481-491. https://doi.org/10.1016/j.tate.2016.07.019.

Fleischmann, E. M. (2013). Soft skills of excellent teachers in diverse South African schools in the Western Cape. (Doctoral dissertation), Stellenbosch University, Stellenbosch. http://scholar.sun.ac.za/handle/10019.1/80131

Ghouri, A. M., Akhtar, P., Shahbaz, M., \& Shabbir, H. (2019). Affective organizational commitment in global strategic partnerships: The role of individual-level microfoundations and social change. Technological Forecasting and Social Change, 
146(C), 320-330. https://doi.org/10.1016/j.techfore.2019.05.025

Gillies, R. M. (2004). The effects of communication training on teachers' and students' verbal behaviours during cooperative learning. International Journal of Educational Research, 41(3), 257-279. https://doi.org/10.16/j.ijer.2005.07.004

Han, J., \& Yin, H. (2016). Teacher motivation: Definition, research development and implications for teachers. Cogent Education, 3(1), 1217819. https://doi.org/10.1080/2331186X.2016.1217819

Harish, S., P. (2006). Changing conflict identities: The case of the Southern Thailand discord. RSIS Working Paper, 107.

Herman, K. C., Reinke, W. M., \& Eddy, C. L. (2020). Advances in understanding and intervening in teacher stress and coping: The Coping-Competence-Context Theory. Journal of School Psychology, 78, 69-74. https://doi.org/10.1016/j.jsp.2020.01.001.

Ibrahim, M., S., Ghavifekr, S., Ling, S., Siraj, S., \& Azeez, M., I., K. (2013). Can transformational leadership influence on teacher commitment towards organization, teaching profession, and student learning? A quantitative analysis. Asia Pasific Education Review, 15(2), 177-190. https://doi.org/10.100 7/s/2564-013-9308-3.

Jackson, T. A., Meyer, J. P., \& Wang, X. H. (2013). Leadership, commitment, and culture: A meta-analysis. Journal of Leadership \& Organizational Studies, 20(1), 84-106. https://doi.org/10.1177/1548051812466919.

Jamal, Y., Zahra, S. T., Yaseen, F., \& Nasreen, M. (2017). Coping strategies and hardiness as predictors of stress among rescue workers. Pakistan Journal of Psychological Research, $32(1)$ 141-154. http://www.pjprnip.edu.pk/pjpr/index.php/pjpr/article/view/390/410.

Jónsdóttir, S. R. (2017). Narratives of creativity: How eight teachers on four school levels integrate creativity into teaching and learning. Thinking Skills and Creativity, 24, 127139. https://doi.org/10.1016/j.tsc.2017.02.008.

Kim, S., Magnusen, M., Andrew, D., \& Stoll, J. (2012). Are transformational leaders a double-edged sword? Impact of transformational leadership on sport employee commitment and job satisfaction. International Journal of Sports Science \& Coaching, 7(4), 661-676. https://doi.org/10.1260/1747-9541.1.7.4.661.

Le Blanc, P. M., \& González-Romá, V. (2012). A team level investigation of the relationship between Leader-Member Exchange (LMX) differentiation, and commitment and performance. The Leadership Quarterly, 23(3), 534-544. https://doi.org/10.1016/j.leaqua.2011.12.006.

Lee, T., W., Ashford, S., J., Walsh, J., P., \& Mowday, R., T. (2000). Commitment propensity, organizational commitment and voluntary turnover: A longitudinal study of organizational entry processees. Journal of Management, 18(1), 15-32. https://doi.org/10.1177/014920639201800102

Liu, Y., Loi, R., \& Ngo, H. (2020). Linking organizational social exchange to intention to leave: Does normative commitment matter? The International Journal of Human Resource Management, 31(13), 1663-1683. https://doi.org/10.1080/09585192.2017.1423097.

Liu, Y., \& Werblow, J. (2019). The operation of distributed leadership and the relationship with organizational commitment and job satisfaction of principals and teachers: A multi-level model and meta-analysis using the 2013 TALIS data. International Journal of Educational Research, 96, 41-55. https://doi.org/10.1016/j.ijer.2019.05.005.

Ly, K. H., Asplund, K., \& Andersson, G. (2014). Stress management for middle managers via an acceptance and commitment-based smartphone application: A randomized controlled trial. Internet Interventions, 1(3), 95-101. 
https://doi.org/10.1016/j.invent.2014.06.003

Matin, H. Z., Jandaghi, G., Karimi, F. H., \& Hamidizadeh, A. (2010). Relationship between interpersonal communication skills and organizational commitment (Case study: Jahad Keshavarzi and University of Qom, Iran). European Journal of Social Sciences, 13(3), 387-398.

https://pdfs.semanticscholar.org/2eec/720d7ca2b7437398398fc84244a0ab61bc1f.pdf.

Meyer, J. P., \& Parfyonova, N. M. (2010). Normative commitment in the workplace: A theoretical analysis and re-conceptualization. Human Resource Management Review, 20(4), 283-294. https://doi.org/10.1016/j.hrmr.2009.09.001.

Meyer, J. P., Stanley, D. J., Herscovitch, L., \& Topolnytsky, L. (2002). Affective, continuance, and normative commitment to the organization: A meta-analysis of antecedents, correlates, and consequences. Journal of Vocational Behavior, 61(1), 2052. https://doi.org/10.1006/jvbe.2001.1842.

Mohd Yusof, F., \& Halim, H. (2014). Understanding teacher communication skills. Procedia-Social and Behavioral Sciences, 155, 471-476. https://doi.org/10.1016/j.sbspro.2014.10.324

Moses, I., Berry, A., Saab, N., \& Admiraal, W. (2017). Who wants to become a teacher? Typology of student-teachers' commitment to teaching. Journal of Education for Teaching, 43(4), 444-457. https://www.tandfonline.com/doi/pdf/10.1080/02607476.2017.1296562?needAccess= true.

Mukherjee, S., Singh, A., \& Mehrotra, S. (2016). Organizational justice in relation to competence, commitment and self-motivation. The International Journal of Indian Psychology, 3(2), 33-59. https://doi.org/10.25215/0302.078

Neininger, A., Lehmann-Willenbrock, N., Kauffeld, S., \& Henschel, A. (2010). Effects of team and organizational commitment-A longitudinal study. Journal of Vocational Behavior, 76(3), 567-579. https://doi.org/10.1016/j.jvb.2010.01.009.

Ngang, K., T., Yie, S., C., \& Shahid, M., A., S. (2015). Quality teaching: Relationship to soft skills acquisition. Procedia-Social and Behavioral Sciences, 177, 284-288. https://doi.org/10.1016/j.sbspro.2015.04.649.

Ngang, T. K., \& Chan, T. C. (2015). Critical issues of soft skills development in teaching professional training: Educators' perspectives. Procedia-Social and Behavioral Sciences, 205, 128-133. https://doi.org/10.1016/j.sbspro.2015.09.039.

Ngang, T. K., Yunus, H. M., \& Hashim, N. H. (2015). Soft skills integration in teaching professional training: Novice teachers' perspectives. Procedia-Social and Behavioral Sciences, 186, 835-840. https://doi.org/10.1016/j.sbspro.2015.04.204.

Pachauri, D., \& Yadav, A. (2014). Importance of soft skills in teacher education programme. International Journal of Educational Research and Technology, 5(1), 22-25.

Paek, S. H., \& Sumners, S. E. (2019). The indirect effect of teachers' creative mindsets on teaching creativity. The Journal of Creative Behavior, 53(3), 298-311. https://doi.org/10.1002/jocb.180

Park, J., J., Long, P., Choe, H., N., \& Schallert, L., D. (2018). The contribution of self compassion and compassion to others to students' emotions and project commitment when experiencing conflict in group projects. International Journal of Educational Research, 88, 20-30. https://doi.org/10.1016/j.ijer.2018.01.009.

Park, J., Lee, J., Lee, H., \& Truex, D. (2012). Exploring the impact of communication effectiveness on service quality, trust and relationship commitment in IT services. International Journal of Information Management, 32(5), 459-468. https://doi.org/10.1016/j.ijinformgt.2012.02.005. 
Pongsudhirak, T. (2006). Conflict and terrorism in Southern Thailand. Contemporary Southeast Asia, 28(1), 160-163.

Raina, R., \& Roebuck, D. B. (2016). Exploring cultural influence on managerial communication in relationship to job satisfaction, organizational commitment, and the employees' propensity to leave in the insurance sector of India. International Journal of Business Communication, 53(1), 97-130. https://doi.org/10.1177/2329488414525453.

Ross, L., Lutfi, G. A., \& Hope, W. C. (2016). Distributed leadership and teachers' affective commitment. NASSP Bulletin, 100(3), 159-169. https://doi.org/10.1177/0192636516681842.

Shen, B., \& Bai, B. (2019). Facilitating university teachers' continuing professional development through peer-assisted research and implementation team work in China. Journal of Education for Teaching, 45(4), 476-480. https://doi.org/10.1080/02607476.2019.1639265.

Smyth, E., Healy, O., \& Lydon, S. (2015). An analysis of stress, burnout, and work commitment among disability support staff in the UK. Research in developmental disabilities, 47, 297-305. https://doi.org/10.1016/j.ridd.2015.09.023.

Somprach, K., Popoonsak, P., \& Sombatteera, S. (2014). Soft skills development to enhance teachers' competencies in primary schools. Procedia-Social and Behavioral Sciences, 112, 842-846. https://doi.org/10.1016/j.sbspro.2014.01.1240

Steffens, N. K., Fonseca, M. A., Ryan, M. K., Rink, F. A., Stoker, J. I., \& Pieterse, A. N. (2018). How feedback about leadership potential impacts ambition, organizational commitment, and performance. The Leadership Quarterly, 29(6), 637-647. https://doi.org/10.1016/j.leaqua.2018.06.001.

Tang, W. G., \& Vandenberghe, C. (2020). Is affective commitment always good? A look at within-person effects on needs satisfaction and emotional exhaustion. Journal of Vocational Behavior, 119, 103411. https://doi.org/10.1016/j.jvb.2020.103411

Yeşil, H. (2010). The relationship between candidate teachers' communication skills and their attitudes towards teaching profession. Procedia-Social and Behavioral Sciences, 9, 919-922. https://doi.org/10.1016/j.sbspro.2010.12.259. 